\title{
CONTRIBUTION OF READING HABIT, READING INTEREST, READING MOTIVATION, READING SELF-EFFICACY TO THE STUDENTS' READING COMPREHENSION IN SENIOR HIGH SCHOOL
}

\author{
K.I.M. Putri ${ }^{1}$, D.K. Tantra ${ }^{2}$, N.P.E. Marsakawati ${ }^{3}$ \\ ${ }^{123}$ English Language Education, Universitas Pendidikan Ganesha, Singaraja \\ e-mail: indah.mahaputri@yahoo.co.id ,dewatantra@yahoo.com ,marsakawatiera@gmail.com
}

\begin{abstract}
The general objective pursued in this research is to describe and predict the students' reading habit, reading interest, reading motivation, and reading self-efficacy to their reading competency in the Senior High School. The design applied is a quantitative research. There were 124 students recruited using cluster sampling technique. Data were gathered using four rating scales and a reading test. The obtained data were analyzed in two phases, namely: descriptively and inferentially. Descriptively, central tendency measures and dispersion were computed for the four predictor variables and one criterion variable. Whereas inferentially, gross and net contributions of the four predictor variables to the criterion variables were computed using regression analysis technique. Descriptively, the mean scores of reading habit, reading interest, reading motivation, reading self-efficacy, and reading comprehension are categorically moderate. The multiple correlation between the predictor variables and the criterion variable is highly significant $(\mathrm{R}=78.7 \%)$. The contribution of the predictor variable to the criterion variable is as much as $61.9 \%$. The research findings imply effective efforts to the betterment of reading habit, interest, motivation, self-efficacy as well as the the students' reading comprehension in SMAN 1 Kuta Selatan.
\end{abstract}

Keywords: Contribution; Reading Comprehension; Senior High School

\section{INTRODUCTION}

Reading is considered as a paramount importance during the era of information technology (McGeown et al. 2015; Alhamdu 2016; Scott and Saaiman 2016). According to McGeown et al., 2015, reading plays a significant role and beneficial for EFL students. Alhamdu (2016) revealed that reading opens many chances to enhance information and knowledge for living. Indeed, the importance of reading becomes a highlight especially in academic aspect (Scott and Saaiman, 2016). People can earn benefits through reading. It is also beneficial for educational success and career opportunity since it introduces new vocabulary and learning to students, builds new information and variety of knowledge (Scott and Saaiman, 2016).

Reading is also important in learning other languages. Especially English language, reading becomes one of important skills since it trains students to implement the comprehension process. The EFL students use reading to learn the language and its structure (A. G. Martinez and Zarobe 2017). Therefore, reading is significantly affected students' understanding on knowledge.

Fridkin (2018) conducted three experimental studies to figure out children's reading comprehension and task enjoyment. The result showed that reading comprehension has important roles in developing students' enjoyment in doing tasks. Another research investigated the correlation of reading comprehension and reading interest (Fahrurrozi, et al. 2020). They found that reading interest was highly significantly correlated with reading comprehension. They argued that reading comprehension is dependent upon the students' reading interest and their willingness to learn. They also concluded that reading is important for education, especially learning English as foreign language.

Reading comprehension trains cognitive process that sustain human to create well mental description (Moore 2014). Although reading gives beneficial effects for students, 
however, many EFL students possessed deficiencies in reading. Data have shown that the students' reading scores were declining in Indonesia. When compared to other countries, Indonesia positioned lowest in the rank when they joined the Program for International Students Assessment (PISA) in 2018. There were 79 countries participated in PISA (Schleicher 2019). As reported in PISA, the Indonesian students' reading scores still showed deficiencies. The students' reading scores, when compared to other countries, were ranked on 72 out of 79 countries. Moreover, their reading mean score dropped to 371 despite the new curriculum has been deployed for five years.

Mohamed (2016) conducted a research about challenges faced by students of English language program towards reading comprehension. It was concluded that low reading comprehension was due to students' general difficulty in learning the language. Moreover, they become less enthusiastic in reading which directly affected their ability in English. It was suggested that teachers' support was needed since it could help students to develop their reading skill.

According to the English teacher's data analysis of students' score in English subject, it showed that the students' reading comprehension is below average in Sekolah Menengah Atas Negeri (SMAN) 1 Kuta Selatan. It has been speculated that the students' low reading comprehension is due to some factors, among others: lack of library management and book collection, technology advances, and lack of family support in providing reading time to enhance children's habits (Crawley and Mountain 1995; Wang and Guthrie 2004; Sherer, M., \& Adams 1983).

A number of previous researches have shown empirical evidences on the roles of reading habit, reading interest, reading motivation, reading self-efficacy on success in the students' reading comprehension. Janes (2008) studied reading motivation and family reading habits of the sixth-grade students at Prairie Elementary School. The findings revealed that there was no significant difference in reading motivation found in pretest to posttest of each group. The role of family as supporter for children's reading motivation is highly affected. Especially, support from parents is beneficial for students in encouraging them to read (Hughes-Hassell, Sandra; Lutz 2006)

Martinez (2019) studied reading self- efficacy which correlated with reading anxiety and the students' reading comprehension. The study used a quantitative correlational design. It was found that there is a positive significant correlation $(r=.332, p<.01)$ among reading self-efficacy and reading comprehension. In addition, a significant correlation found negatively between reading self-efficacy and reading anxiety $(r=-.345, p<.01)$.

Celik (2019) studied reading habit in children. He concluded that reading habit enhanced knowledge and broadened information. Reading has good effect for individuals' intellectual growth. The habit of reading could be trained from childhood or youth period, yet reading habits is not about reading textbooks to gain knowledge since reading can be done in leisure time. Reading fiction books as novels, fairytales, magazines improve individuals' perception and language expertise. Family, school and library have a crucial role in students' reading habits. All parties should be cooperative in encouraging students to get used in reading for specific purpose or for relaxing mind. School provides library that can help teachers in driving students to read as many as possible.

When analyzed critically, those researches were related to the students' problem in SMAN 1 Kuta Selatan. Mainly related to the cause of students' below reading comprehension. The present research was conducted to aggregate four aspects related to the problem as predictor variables, namely: reading habit, reading interest, reading motivation, reading self-efficacy and one criterion variable, that is, the students' reading comprehension. This research was designed in a quantitative survey using Linear Regression Analysis to predict the individual and multiple gross as well net contribution of reading habit, reading interest, reading motivation, reading self-efficacy to the students' reading comprehension in the Senior High School.

\section{RESEARCH METHOD}

The design used quantitative research using rating scales to measure the students' reading habit, reading interest, reading motivation, reading self-efficacy, and a multiplechoice test to measure the students' reading comprehension. Data were analyzed 
descriptively, and inferentially using measures of central tendency and dispersion, pair-wise correlation, multiple correlation, and multiple linear regression analysis. The population totaled 339 students clustered in six intact classes (Hinkle 1979; Gall, et al. 2007). There were 124 students selected as the sample who were selected by means of cluster sampling technique.

There were four predictor variables. First variable is reading habit with its indicators, namely: 1) Automaticity, 2) frequency, and 3) self-identity (Verplanken and Orbell 2003). Second variable is reading interest with its indicators, namely: 1) previous experience, 2) selfconcept, 3) value, 4) understandable subject and, 5) level of pressure involvement, and 6) complexity of subject material (Crawley and Mountain, 1995), Third variable is reading motivation with its indicators, namely: 1) curiosity, 2) involvement, 3) challenge (Wang and Guthrie, 2004). Fourth variable is reading self-efficacy with its indicators, namely: 1) initiative,2) effort, and 3) persistence (Sherer, M., \& Adams 1983). Fifth variable is reading comprehension with its indicators, namely: 1) main idea, 2) specific ideas, 3) textual references, and 4) word meanings (Latifa and Manan 2018).

There were five instruments used, namely: Reading Habit Rating Scale, Reading Interest Rating Scale, Reading Motivation Rating Scale, Reading Self-Efficacy Rating Scale, and Reading Comprehension Test. Prior to administration of those instruments, they were validated and tried out to test the readability, reliability, validity, except the reading comprehension test was tried out to check the item's difficulty and discrimination indices (Gregory 2007; Candiasa 2011; Retnawati 2016). The five instruments were administered to 4 different classes simultaneously through online platform. The students worked independently for 30 minutes, except the reading comprehension test they were allocated for 60 minutes to complete the test.

The obtained data were analyzed descriptively and inferentially. Descriptively, the five variables were computed each of its mean, standard deviation, range, and variance. Inferentially, pair-wise correlations, multiple correlation, and multiple prediction were computed using Multiple Linear Regression Analysis (Hinkle 1979)

\section{FINDINGS AND DISCUSSION}

There are two hypothesizes conducted in this study, such as: H0) There is a significant multiple correlation of reading habit, reading interest, reading motivation, reading self-efficacy to the students' reading comprehension in SMAN 1 Kuta Selatan, and H1) There is a significant multiple contribution of reading habit, reading interest, reading motivation, reading self-efficacy to the students' reading comprehension in SMAN 1 Kuta Selatan. Prior to testing the hypothesis, data on the students' students' reading habit, reading interest, reading motivation, reading selfefficacy, and reading comprehension are described in the following table.

\begin{tabular}{cccccc}
\multicolumn{7}{c}{ Table 1. Descriptive Statistics of Variables } \\
\hline & $\begin{array}{c}\text { Reading } \\
\text { Habit }\end{array}$ & $\begin{array}{c}\text { Reading } \\
\text { Interest }\end{array}$ & $\begin{array}{c}\text { Reading } \\
\text { Motivation }\end{array}$ & $\begin{array}{c}\text { Reading } \\
\text { Self-Efficacy }\end{array}$ & $\begin{array}{c}\text { Reading } \\
\text { Comprehension }\end{array}$ \\
\hline $\begin{array}{c}\text { Nean } \\
\text { Mean }\end{array}$ & 124 & 124 & 124 & 124 & 124 \\
$\begin{array}{c}\text { Mean } \\
\text { Std. }\end{array}$ & 50.20 & 48.57 & 30.42 & 26.43 & 68.54 \\
$\begin{array}{c}\text { Deviation } \\
\text { Variance }\end{array}$ & .39 & .50 & .60 & .30 & .54 \\
\hline
\end{tabular}

Source: Data Analysis per-January 2021 SPSS Version 25.

The students' reading habit, reading interest, reading motivation, reading self-efficacy, and reading comprehension are $50.20,48.57,30.42,26.43,68.54$ respectively. Whilst, the standard deviations are 4.39, 5.57, 6.74, 3.37, 6.05 respectively. When the five variables are analysed categorically using the following criteria, the results are shown as follows: 
Table 2. Categories of the Five Variables

\begin{tabular}{lll}
\hline Predictor and Criterion Variables & Mean & Category \\
\hline Reading Habit & 50.20 & Moderate Category \\
Reading Interest & 48.57 & Moderate Category \\
Reading Motivation & 30.42 & Moderate Category \\
Reading Self-Efficacy & 26.43 & Moderate Category \\
Reading Comprehension & 68.54 & Moderate Category \\
\hline
\end{tabular}

Source: Data Analysis per-January 2021 SPSS Version 25.

According to the table above, it was found that the students' reading habit (Mean = 50.20 ), reading interest (Mean $=48.57$ ), reading motivation (Mean $=30.42$ ), reading selfefficacy (26.43), are categorically moderate; then, their reading comprehension is categorically moderate (Mean $=68.54)$. Further analysis was performed on the scores variability of the students' reading habit, reading interest, reading motivation, reading selfefficacy, and reading comprehension in SMA Negeri 1 Kuta Selatan. The variabilities are ordered from largest to smallest, as follows: reading comprehension (Variance $=36.64$ ), reading self-efficacy $($ Variance $=11.37$ ), reading motivation (Variance $=45.50)$, reading interest $($ Variance $=31.06)$, reading habit $($ Variance $=19.30)$.

\section{Pair-Wise Correlations}

After analyzing the students' reading habit, reading interest, reading motivation, reading self-efficacy, and reading comprehension descriptively, the pair-wise correlation of the predictor and criterion variables were computed. The results are shown in the following table.

Table 3. Pair-Wise Correlations

\begin{tabular}{lccccc}
\hline & $\begin{array}{c}\text { Reading } \\
\text { Comprehen } \\
\text { sion }\end{array}$ & $\begin{array}{c}\text { Reading } \\
\text { Habit }\end{array}$ & $\begin{array}{c}\text { Reading } \\
\text { Interest }\end{array}$ & $\begin{array}{c}\text { Reading } \\
\text { Motivation }\end{array}$ & $\begin{array}{c}\text { Reading Self- } \\
\text { Efficacy }\end{array}$ \\
\hline $\begin{array}{l}\text { Reading Habit } \\
\text { Reading }\end{array}$ & .639 & 1.000 & .241 & .280 & .422 \\
$\begin{array}{l}\text { Interest } \\
\text { Reading }\end{array}$ & .532 & .241 & 1.000 & .167 & .318 \\
$\begin{array}{l}\text { Motivation } \\
\text { Reading Self- }\end{array}$ & .397 & .280 & .167 & 1.000 & .329 \\
$\begin{array}{l}\text { Efficacy } \\
\text { Reading Habit }\end{array}$ & .526 & .422 & .318 & .329 & 1.000 \\
\hline
\end{tabular}

Source: Data Analysis per-January 2021 SPSS Version 25.

Reading the above table, the correlation of reading comprehension and reading habit, reading interest, reading motivation, and reading self-efficacy pair-wisely are concluded as follows.

1) Very High significant correlation between reading comprehension and reading habit $r$ $=0.639$;

2) Very High significant correlation between reading comprehension and reading interest $r=0.532$;

3) High significant correlation between reading comprehension and reading motivation $r$ $=0.397$;

4) Very High significant correlation between reading comprehension and reading selfefficacy $r=0.526$.

\section{Multiple Correlation}

After analyzing the pair-wise correlation of the students' reading habit, reading interest, reading motivation, reading self-efficacy, and reading comprehension, the multiple correlation of the predictor and criterion variables were computed. The result is shown in the 
following table.

Table 4. Multiple Correlation: Predictor and Criterion Variables

$\begin{array}{ccc}\mathrm{R} & \text { Std. Error of the Estimate } & \text { Durbin-Watson } \\ 0.787 & 3.79939 & 1.972\end{array}$

Source: Data Analysis per-January 2021 SPSS Version 25.

The above table shows clearly that reading habit, reading interest, reading motivation, reading self-efficacy could account as much as $78.7 \%$ of the students' reading comprehension in SMAN 1 Kuta Selatan. It is revealed that there was multiple correlation between students' reading habit, reading interest, reading motivation, reading self-efficacy as the predictor variables and the reading comprehension as criterion variable in SMA Negeri 1 Kuta Selatan as much as $78.7 \%$ and remaining $21.3 \%$ explained by other variables which not discuss in this present research.

\section{Multiple Prediction}

The final data analysis was proceeded to contribution of reading habit, reading interest, reading motivation, reading self-efficacy to reading comprehension using the Multiple Linear Regression Analysis Technique. The data analysis result is shown in the following table.

Table 5. Summary of Contribution: Predictor and Criterion Variables

\begin{tabular}{cccc}
\hline Model & R Square & Adjusted R Square & Std. Error of the Estimate \\
\hline Enter & .619 & 0.606 & 3.79939 \\
\hline
\end{tabular}

Source: Data Analysis per-January 2021 SPSS Version 25.

The above table shows gross and net contributions of reading habit, reading interest, reading motivation, reading self-efficacy to reading comprehension. The gross contribution of reading habit, reading interest, reading motivation, reading self-efficacy to reading comprehension or $\mathrm{R}$ square is 0.619 or $61.9 \%$. The net contribution of the predictor variables to the criterion variable or adjusted $\mathrm{R}$ square is 0.606 or $60.6 \%$. Similar in meaning, the four predictor variables could account for $61.9 \%$ reading comprehension variances. Concludingly, reading habit, reading interest, reading motivation, and reading self-efficacy contributed to the students' ability in comprehending descriptive and recount texts with its own variations.

The research findings clearly evidenced full contribution of the the predictor variables to the criterion variable. The students' reading comprehension ability were related to their reading habit, reading interest, reading motivation, reading self-efficacy. As Verplanken and Orbell (2003) described that frequency of daily or weekly students' behavior for reading, and the personal style to reading could contribute significantly in find text's main idea, specific information, determining textual reference as well as getting word/phrase/sentence meaning. Similar to reading habit, Takaloo and Ahmadi (2017) argued that the students' reading interest, especially ample experience in reading, valuing reading, and high level of involvement in reading would enhance comprehension of the reading indicators.

The other two variables, they are: reading motivation and reading self-efficacy function similar to reading habit and reading interest. Motivation is a factor that affect someone to do action for achieving the purpose (Takaloo and Ahmadi 2017). Self-efficacy is defined as self-confidence of someone to fulfill the goals without hesitation (Bandura 1997). In reading, self-efficacy means that students' confidence in comprehending a passage and ability to understand. Reading self-efficacy is a psychological factor influencing students' motivation in reading skill (Hasriati 2017). In the present research, the four variables effectively contributed to the students' reading comprehension in SMAN 1 Kuta Selatan.

\section{CONCLUSION AND SUGGESTIONS}

The present research yielded three major findings which could be concluded as follows: The students' reading habit, reading interest, reading motivation, reading selfefficacy, and reading comprehension are categorically moderate. The students' reading habit, reading interest, reading motivation, reading self-efficacy were significantly and multiply correlated to the students' reading comprehension ability in SMAN 1 Kuta Selatan.The Jurnal Pendidikan Bahasa Inggris Indonesia | 29 
students' reading habit, reading interest, reading motivation, reading self-efficacy were contributed as much as $6.7 \%$ to the students' reading comprehension ability in SMAN 1 Kuta Selatan.

It is suggested to develop school literacy program with the following activities. In order to build a wide vocabulary and broad background knowledge, students need to read in a wide variety of genres and text types. Through book talks, read alouds, and book displays, open students' eyes to new authors, genres, and text types. The aim of school literacy is to raise literacy attainment at every level of ability. School staff together integrate the skills of listening, speaking, reading and writing into the curriculum to maximize the potential of each student. Six strategies are suggested to be implemented to affect reading habit, interest, motivation, self-efficacy as well as reading comprehension, they are, making connections, visualizing, inferring, questioning, determining importance, and synthesizing.

\section{REFERENCES}

Alhamdu. 2016. "Interest and Reading Motivation." Psikis: Jurnal Psikologi Islami 1 (1): 1-10. https://doi.org/10.19109/psikis.v1i1.552.

Bandura, A. 1997. Self-Efficacy: The Excercise of Control. New York: W.H. Freeman and Company.

Candiasa, I. M. 2011. "Pengujian Instrumen Penilaian Disertai Aplikasi Iteman Dan Bigsteps." In . Singaraja: Undiksha Press.

Celik, B. 2019. "A Study on Using the University Library and Reading Habits of Students: A Study on Tishk International University Students in Erbil, Iraq." International Journal of English Linguistics 9 (4): 224. https://doi.org/10.5539/ijel.v9n4p224.

Crawley, S. J., and L. Mountain. 1995. Strategies for Guiding Content Reading. Order Processing Allyn \& Bacon. Des Moines, IA 50336-1071.

Fahrurrozi, R.\& Hasanah, U.. 2020. "The Influence of Reading Interests, Vocabulary Mastery and Critical Thinking on Reading Comprehension in Elementary School Students." International Journal of Psychosocial Rehabilitation 24 (8): 1630-40. https://doi.org/10.37200/IJPR/V24I8/PR280182.

Fridkin, L. 2018. "The Impact of Motivation on Children's Reading Comprehension: Differential Effects of Gender and Ability." Journal of Chemical Information and Modeling 53 (9): 287.

Gall, M., J. Gall, and W. Borg. 2007. Educational Research: An Introduction (8th Ed.). Boston: Pearson Education.

Gregory, R.J. 2007. Psychological Testing: History, Principles, and Applications. Boston: Pearson Education.

Hasriati. 2017. "Reading Anxiety, Reading Self-Efficacy And Vocabulary As Predictors Of Students' Reading Comprehension." Journal of Language Education and Educational Technology 2 (1).

Hinkle, et al. 1979. "Apllied Statistics for the Behavioral Sciences." In , 1979. New York: Houghton Mifflin Company.

Hughes-Hassell, Sandra; Lutz, Christina. 2006. "What Do You Want to Tell Us about Reading?: A Survey of the Habits and Attitudes of Urban Middle School Students toward Leisure Reading." Young Adult Library Services 4 (2): 39-45. http://search.ebscohost.com/login.aspx?direct=true\&db=aph\&AN=19689001\&site=eh ost-live.

Janes, J. L. 2008. "Families, Motivation, and Reading." lowa State University.

Latifa, N. \& Manan, A. 2018. "Teaching Narrative Text by Using Preview, Question, Read, State, and Test (PQRST) Technique." "English Education Journal" 9 (2): 243-60.

Martinez, A.G. \& de Zarobe, Y. R. 2017. "ComparingtThe Benefits of a Metacognitive 
Reading Strategy Instruction Programme Between CLIL and EFL Primary School Students". Estudios de Lingüística Inglesa Aplicada 6: 267-74. http://www.ncbi.nlm.nih.gov/entrez/query.fcgi?cmd=Retrieve\&db=PubMed\&dopt=Citat ion\&list_uids=19893492.

Martinez, K. E. 2019. "The Relationship among Reading Self-Efficacy, Reading Anxiety, and Reading Comprehension Performance." ProQuest Dissertations and Theses, 194. http://0-

search.proquest.com.pugwash.lib.warwick.ac.uk/docview/2224646158?accountid=14 888\%0Ahttp://webcat.warwick.ac.uk:4550/resserv??genre=dissertations+\%26+theses \&issn=\&title=The+Relationship+among+Reading +SelfEfficacy\%2C+Reading+Anxiety\%2C+and+Reading.

McGeown, S. P., Duncan, L. G, Griffiths, Y.M. \& Stothard, S.E. 2015. "Exploring the Relationship between Adolescent's Reading Skills, Reading Motivation and Reading Habits." Reading and Writing 28 (4): 545-69. https://doi.org/10.1007/s11145-0149537-9.

Mohamed. 2016. "Evaluating EFL Students' Reading Comprehension Skills with Reference to the Department of English at Zawia University," no. April.

Moore, A.L. 2014. "A Research Review of Cognitive Skills, Strategies, and Intervention Reading Comprehension." Welland: ASP.

Retnawati, H. 2016. Analisis Kuantitatif Instrument Penelitian: Panduan Peneliti, Mahasiswa Dan Psikometrian. Yogyakarta: Parama Publishing.

Schleicher, A. 2019. "PISA 2018: Insights and Interpretations." OECD Publishing.

Scott, L.\& Saaiman, E. 2016. "Promoting Reading Skills or Wasting Time? Students' Perceived Benefits of Reading in an Intermediary Programme at the Vaal University of Technology." Reading \& Writing 7 (1): 1-12. https://doi.org/10.4102/rw.v7i1.82.

Sherer, M., \& Adams, C. H. 1983. "Construct Validation of the Self-Efficacy Scale." Psychological Reports 53 (3): 899-902.

Takaloo, N. M. \& Ahmadi, M. R. 2017. "The Effect of Learners' Motivation on Their Reading Comprehension Skill: A Literature Review." International Journal of Research in English Education 2 (3): 10-21. https://doi.org/10.18869/acadpub.ijree.2.3.10.

Verplanken, B. \& Orbell, S. 2003. "Reflections on Past Behavior: A Self - Report Index of Habit Strength 1." Journal of Applied Social Psychology 33 (6): 1313-30.

Wang, J. H-Y \& Guthrie, J.T. 2004. "Modeling the Effects of Intrinsic Motivation, Extrinsic Motivation, Amount of Reading, and Past Reading Achievement on Text Comprehension between U.S. and Chinese Students." Reading Research Quarterly 39 (2): 162-86. https://doi.org/10.1598/rrq.39.2.2. 